\title{
Nonstructural carbohydrates and spring regrowth of two cool-season grasses: Interaction of drought and clipping
}

\author{
C.A. BUSSO, J.H. RICHARDS, AND N.J. CHATTERTON
}

\section{Abstract}

The role that accumulated carbohydrates play in plant regrowth has been discussed for over 60 years. However, few quantitative studies have been published on the importance of carbohydrates for regrowth in early spring after plants have been exposed to periods of either drought or drought plus defoliation. We examined the relationship between total nonstructural carbohydrate (TNC) concentrations and pools (biomass $X$ concentration) and spring regrowth for crested wheatgrass [Agropyron desertorum Fisch. ex Link) Schult.] and bluebunch wheatgrass [Pseudoroegneria spicata (Pursh) A. Löve ssp. spicata; Syn: A. spicatum (Pursh) Scribn. and Smith] with and without clipping under drought, natural, and irrigated conditions.

In spring 1985 and early spring 1986, after 1 or 2 years of clipping, crown and root TNC concentrations and TNC pools per tiller were generally similar for clipped and unclipped plants of both species. Nonstructural carbohydrate concentrations in crowns and roots did not relate to rate or total production of dark regrowth in mid-spring 1985 and early spring 1986 . In early spring 1986 following 2 years of repeated treatments, crown and root TNC pools were on average 7 times higher under drought, in both clipped and unclipped plants, than they were under the higher moisture-Jevel treatments for both species. The large pools of TNC in drought-treated plants appeared to enhance the production of dark regrowth when meristematic limitations on growing tillers did not exist in early spring. These results suggest that plants exposed to prolonged periods of drought or drought plus defoliation may have rapid initial regrowth upon alleviation of these stresses because high amounts of TNC may have accumulated in their storage organs during stress. In addition, the results suggest that high TNC availability facilitates growth only when meristematic activity is high.

Key Words: Agropyron desertorum, Pseudoroegneria spicata, water stress, defoliation

Nonstructural carbohydrates are important in initiating regrowth when photosynthetic tissues are nonexistent or are inadequate to supply both respiration and growth demands (Heilmeier et al. 1986). However, the role played by accumulated carbohydrates in plant regrowth has been the subject of much controversy. Many investigators (e.g., Cook 1966, Daer and Willard 1981) have concluded that accumulated carbohydrates have a fundamental role in plant regrowth. Richards and Caldwell (1985), however, demonstrated that crown carbohydrate concentrations or pools (biomass $X$ concentration) were not related to dark regrowth rate or production in crested wheatgrass [Agropyron desertorum (Fisch. ex Link)

\footnotetext{
Authors are assistant professor, Centro de Recursos Naturales Renovables de la Zona Semiárida and Departamento de Agronomia, Universidad Nacional de Sur, 8000 Bahla Blanca, Argentina; associate professor, Department of Range Science and the Ecology Center, Utah State University, Logan 84322-5230; and research scientist, USDA-ARS Forage and Range Research Laboratory, Utah State University, Logan, Utah 84322-6300. At the time of research, the senior author was a Fellow of the Consejo Nacional de Investigationes Cientificas y Técnicas de la República Argentina (CONICET) and graduate research assistant, Department of Range Science, Utah State University, Logan.

This research was funded by the U.S.U. Faculty Grant Program and the National Science Foundation (BSR-8705492). We thank A. Busso and A. Maldonado for technical assistance on conducting this research and R.W. Brown and D.A. Johnson for cooperation in the field. Journal paper 3765 of the Utah Agricultural Experiment Station.

Manuscript accepted 21 December 1989.
}

Schult.] and bluebunch wheatgrass [Pseudoroegneria spicata (Pursh) A. Löve ssp. spicata; Syn: A. spicatum (Pursh) Scribn. and Smith]. In their experiments throughout the growing season, the number of actively growing meristems was more important than carbohydrate availability in limiting regrowth rate or production. Carbohydrate concentrations or pools may become more important in limiting regrowth in early spring, however, when active intercalary and apical meristems are present in regrowing tillers of these rangeland grasses.

Carbohydrates often accumulate in water-stressed plants because growth is impaired before photosynthesis declines (Dina and Klikoff 1973, Hsiao 1973, Deregibus et al. 1982). If carbohydrates limit plant regrowth when an adequate number of active meristems are present, carbohydrate accumulation could stimulate growth in the early spring of the year following drought or drought plus defoliation, 2 common stresses to which range plants are exposed (Ludlow 1986).

We sought to determine whether the availability of crown and root total nonstructural carbohydrates (TNC) influences growth in early spring after periods of drought or drought plus defoliation in 2 cool-season range grasses, crested wheatgrass and bluebunch wheatgrass. Because numerous meristems are present and active on tillers of these species in early spring, this should also be the period when the potential limitation of growth by TNC availability is greatest. The 2 study species provide an important spring forage resource on the semiarid rangelands of the Intermountain West (Dewey and Asay 1975, West 1983), but differ greatly in their tolerance of grazing (Caldwell et al. 1981). The grazing-tolerant species, crested wheatgrass, was introduced from Eurasia while the grazing-intolerant species, bluebunch wheatgrass, is native to the Intermountain West. Both species often must regrow in spring after being grazed during late-season drought in the preceding year.

\section{Materials and Methods}

\section{Study Area and Plant Material}

This study was conducted at the Green Canyon Ecology Center Research Area, $4 \mathrm{~km}$ northeast of Logan, Utah (41 $45 \mathrm{~N}, 111^{\circ}$ $48^{\prime} \mathrm{W}, 1460 \mathrm{~m}$ a.s.l.). The area is representative of semiarid foothill rangelands of the North American Intermountain West. Crested wheatgrass, bluebunch wheatgrass, and mountain big sagebrush [Artemisia tridentata spp. vaseyana (Rydb.) Beetle] were transplanted into $8 \times 8 \mathrm{~m}$ experimental plots in 1978 (Caldwell et al. 1981). Grasses and shrubs alternate in a regular $0.5 \mathrm{~m} \times 0.5 \mathrm{~m}$ matrix in the plots. Each plot used in this study had 72 plants of each grass species and 145 plants of $A$. tridentata. Mountain big sagebrush provided a natural competitive background. Caldwell et al. (1981) provide more detailed site and climate information.

\section{Experimental Treatments}

Drought, natural, and irrigated treatments were imposed on 3 plots (1 plot for each water-level). A rainout shelter, which was used to impose the drought treatment (Arkin et al. 1976), automatically covered the drought plot whenever a sensor was moistened by precipitation during the growing seasons of 1984, 1985, and 


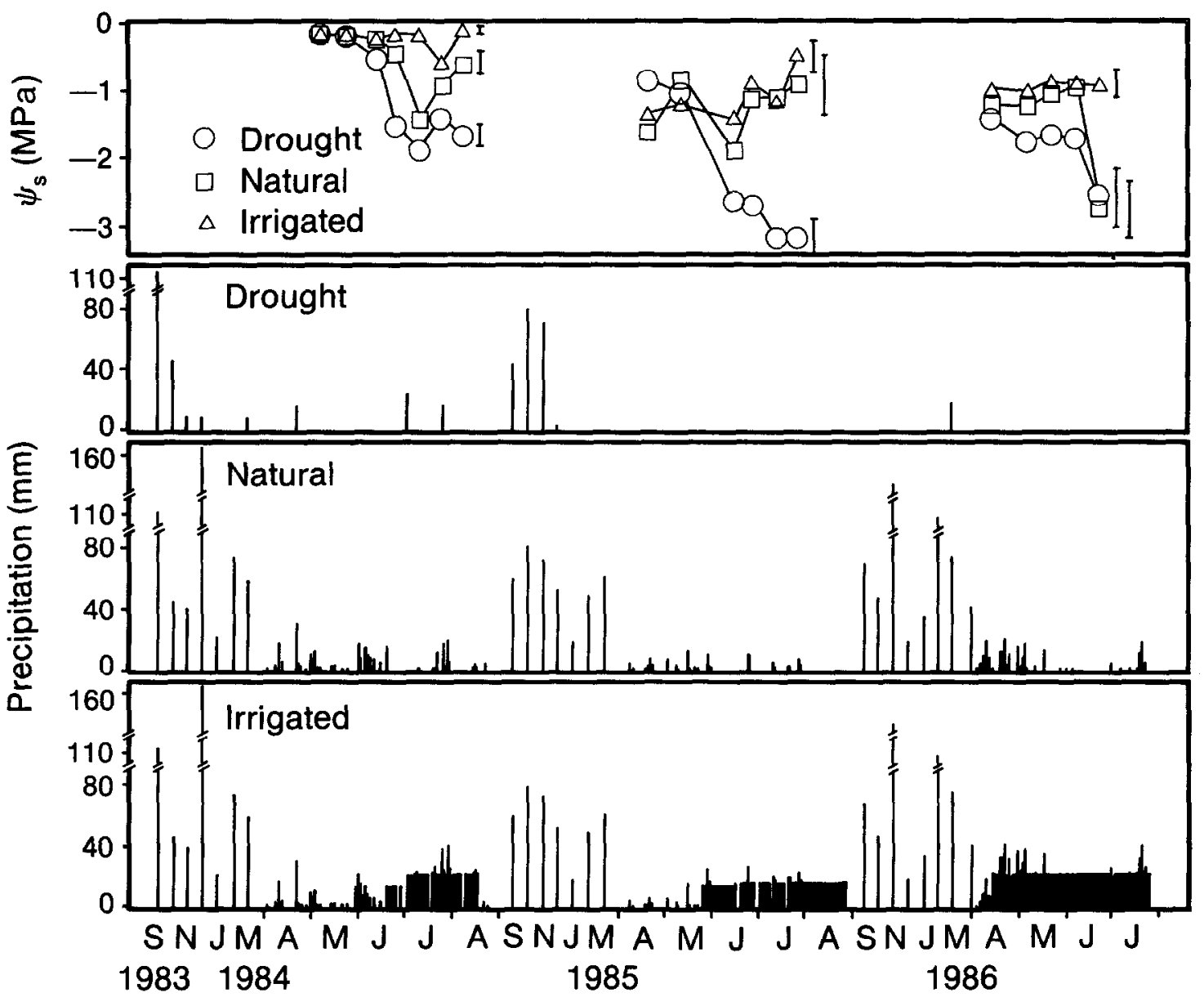

Fig. 1. Soil water potentials $(\Psi$ ) averaged over all measured depths $(10,20,35,50$, and $80 \mathrm{~cm})$ in drought, natural, and irrigated plots during the growing seasons of 1984, 1985, and 196. Each symbol is a mean of 3 or 4 psychrometer observations at each depth. Vertical bars indicate $2 x$ the average SE of the mean for each water level. Seasonal distributions of precipitation events on drought, natural, and irrigated plots from September 1983 until July 1986 are shown in the 3 lower panels. The blackened areas represent water added by drip-irrigation $\left(\sim 20 \mathrm{~mm} \mathrm{day}^{-1}\right)$.

1986. This plot, however, received small amounts of precipitation from autumn 1983 through autumn 1984 and in early spring 1986 (Fig. 1). The natural plot received naturally occurring rain or snow, and the irrigated plot was drip irrigated $\left(\sim 20 \mathrm{~mm}\right.$ day $^{-1}$ during the periods of study, Fig. 1).

Soil water potential was measured in each plot every 10-15 days in 1984,1985 , and 1986 using individually calibrated, screen-cage, thermocouple psychrometers at depths of $10,20,35,50$, and $80 \mathrm{~cm}$.

Grasses in one half of each plot were unclipped controls and those in the other half of each plot were clipped once each year (29 June 1984, 13 June 1985, and 18 May 1986) leaving a 5-7- cm stubble. This timing and intensity of clipping simulated moderateto-heavy late spring cattle grazing (Norton and Johnson 1983, Olson and Richards 1988). In this semiarid region, traditional pasture management results in most plants being grazed only once during the spring and early summer (Norton and Johnson 1983, 1986). Grass plants used in the dark regrowth experiments did not receive this clipping treatment in the year the dark regrowth experiment was conducted.

\section{Dark Regrowth Experiments}

Dark regrowth experiments allowed us to determine the relationship between accumulated crown and root carbohydrates and regrowth capacity, without confoundment by carbohydrate input from photosynthesis (see Richards and Caldwell 1985). Three plants from each of the 12 treatments ( 2 species, 3 water levels, clipped and control) were destructively harvested at the beginning of each dark regrowth experiment (17 to 21 May in 1985, 28 March to 5 April in 1986) to provide estimates of initial crown and root TNC concentrations. These plants could not be used to provide initial TNC pool estimates because they were smaller than the different set of plants reserved for dark regrowth measurements.

The total number of tillers was counted on each harvested plant. Crowns (which included the lowest $1 \mathrm{~cm}$ of stem base and $1 \mathrm{~cm}$ of all attached roots) and roots contained in a $4 \mathrm{dm}^{3}$ soil volume directly underneath each harvested plant were manually washed free of soil and litter. In addition, roots included in 6 soil cores $(0.16$ $\mathrm{dm}^{3}$ each) were washed free of soil with a root washing machine (Smucker et al. 1982). The 6 soil cores were spaced around and under the plant to uniformly sample the root system: $2-17.5 \mathrm{~cm}$ horizontally, $2-32.5 \mathrm{~cm}$ obliquely, and $2-32.5 \mathrm{~cm}$ vertically from the plant center. After washing the root samples, sagebrush roots and debris were removed manually. Crown and root samples were freeze-dried, weighed, and ground to pass a 60 -mesh screen for TNC determinations.

Dark regrowth measurement was initiated by removing as much aboveground biomass as possible with little or no damage to active meristems on the growing tillers. The dark regrowth experiment in 1985 (28 May) was initiated by removing leaf blades, green stems, and sheaths above $\sim 90 \%$ of the tiller apical meristems. All the 

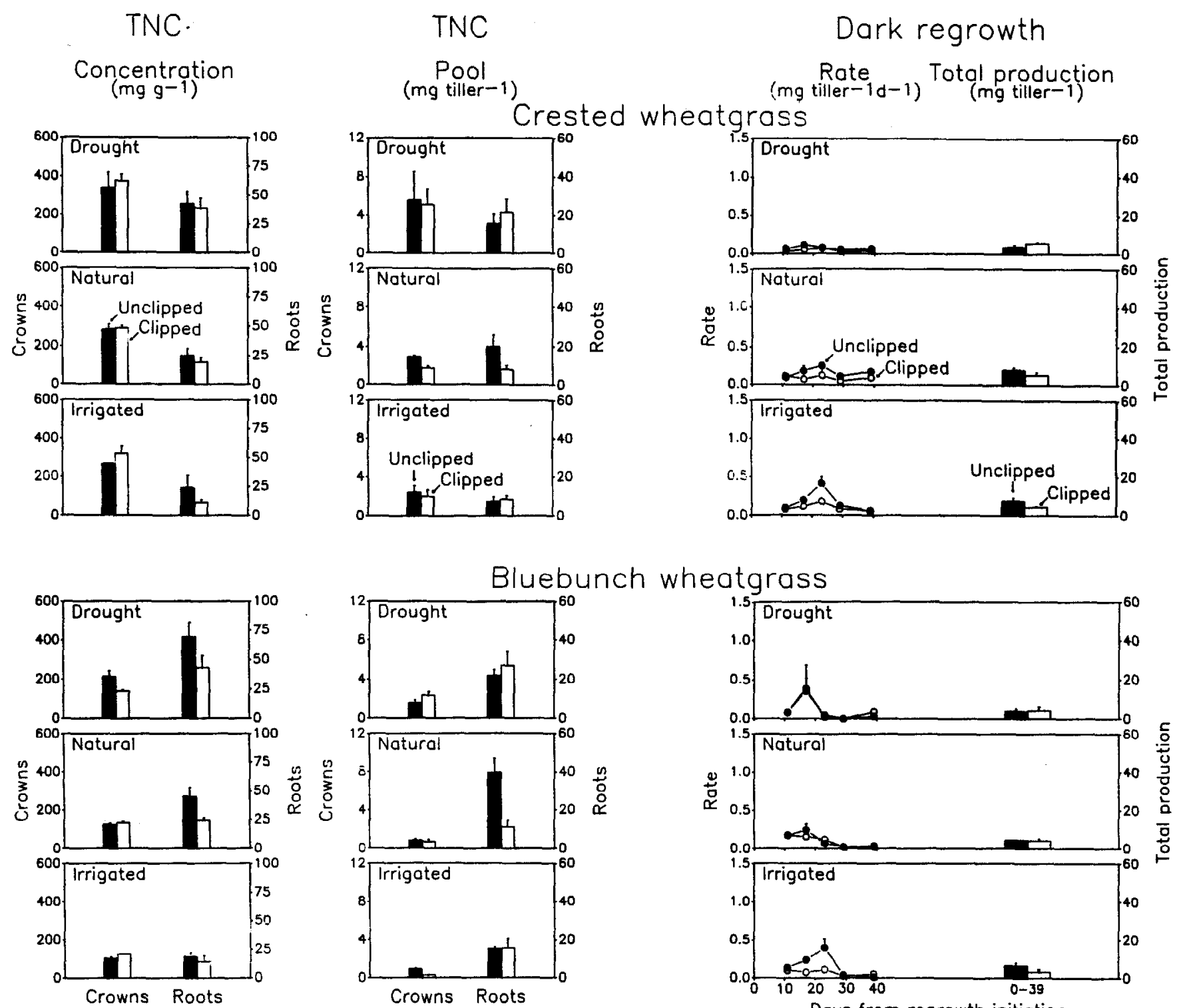

wheatgrass

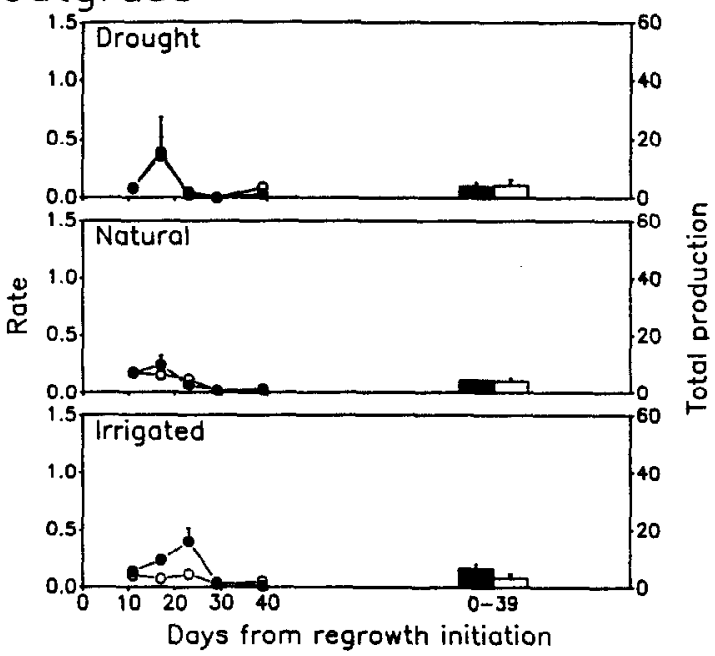

Fig. 2. Crown and root total nonstructural carbohydrate (TNC) concentrations (left panels) and pools (middle panels) at the initiation of the dark regrowth experiment in May 1985, and the time course of leaf blade dark regrowth rate and total dark regrowth (blades plus stems and sheaths) (right panels) from $28 \mathrm{May}$ (day 0 ) untll 6 July (day 39) for plants of crested wheatgrass and bluebunch wheat grass. Plants had been previously clipped or were unclipped under drought, natural or irrigated conditions since 1984. All bars or symbols are means of 3 plants. Vertical bars represent 1 SE.

remaining leaf blades were also cut, above the ligule, so that only stem and sheaths remained. In 1986, only leaf blades (i.e., no removal of apical meristems) were removed from the tillers at the initiation of the dark regrowth experiment (19 April). Each plant was covered with an opaque container to eliminate light, and thus, carbon input from photosynthesis. Leaf blades produced in the dark were harvested at frequent intervals (6-10 days) until regrowth ceased. This procedure eliminated any possible limitations of regrowth by inadequate meristematic activity because active intercalary and apical meristems remained on growing tillers of both species. In addition, because of the imposed darkness, any regrowth was dependent on previously accumulated carbon.

Each year at the end of the dark regrowth experiment, all 36 plants ( 12 treatments, 3 plants per treatment) were destructively harvested in the manner previously described. Shoots were separated into upper leaves, stems, and sheaths produced in the dark, and into lower stems and sheaths that were present at the initiation of dark regrowth. All harvested plant materials were freeze-dried, weighed, and ground for TNC analysis.

At the end of previous dark regrowth experiments, crown and root biomasses were $55 \%$ of initial biomasses (Richards and Caldwell 1985). This value was consistent for experiments initiated at different times during the year and for both species (see Table 1 , Richards and Caldwell 1985). Because this value was extremely consistent, it was used to derive initial biomass estimates in this study (estimated initial biomass=final biomass $/ 0.55$ ). Then, initial TNC pools were calculated by multiplying the estimated initial biomass of the organ by its measured initial carbohydrate concentration.

The Mann-Whitney U-Test (Zar 1984) was utilized to assess statistical differences among treatments. The maximum level of significance that can be achieved with this test is $P=0.08$ for $n=3$. Production of dark regrowth was regressed on TNC concentrations or pools in crowns and roots. 
TNC

Concentration $\left(\mathrm{mg} \mathrm{g} \mathrm{g}^{-1)}\right.$
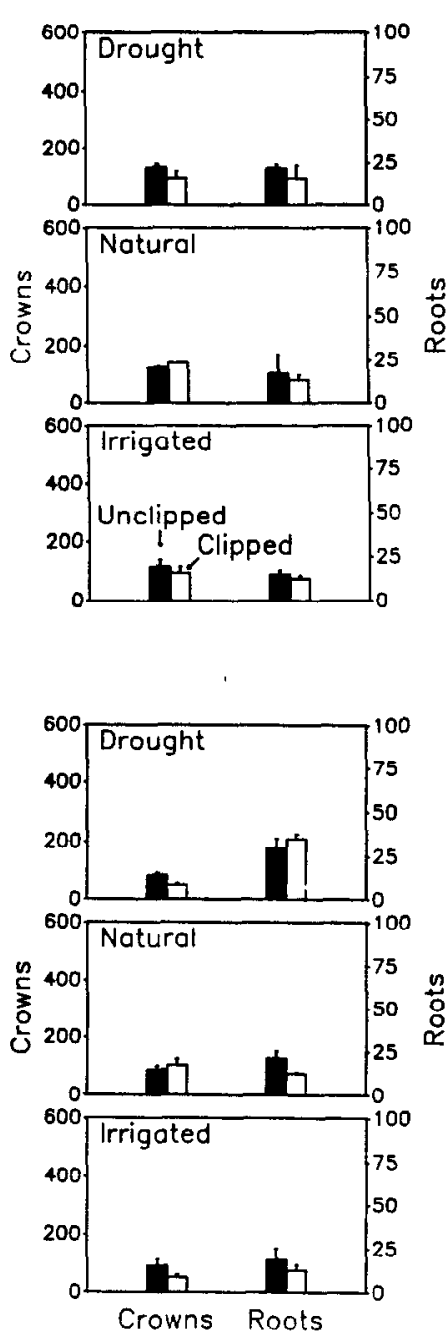

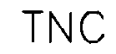

Dark regrowth

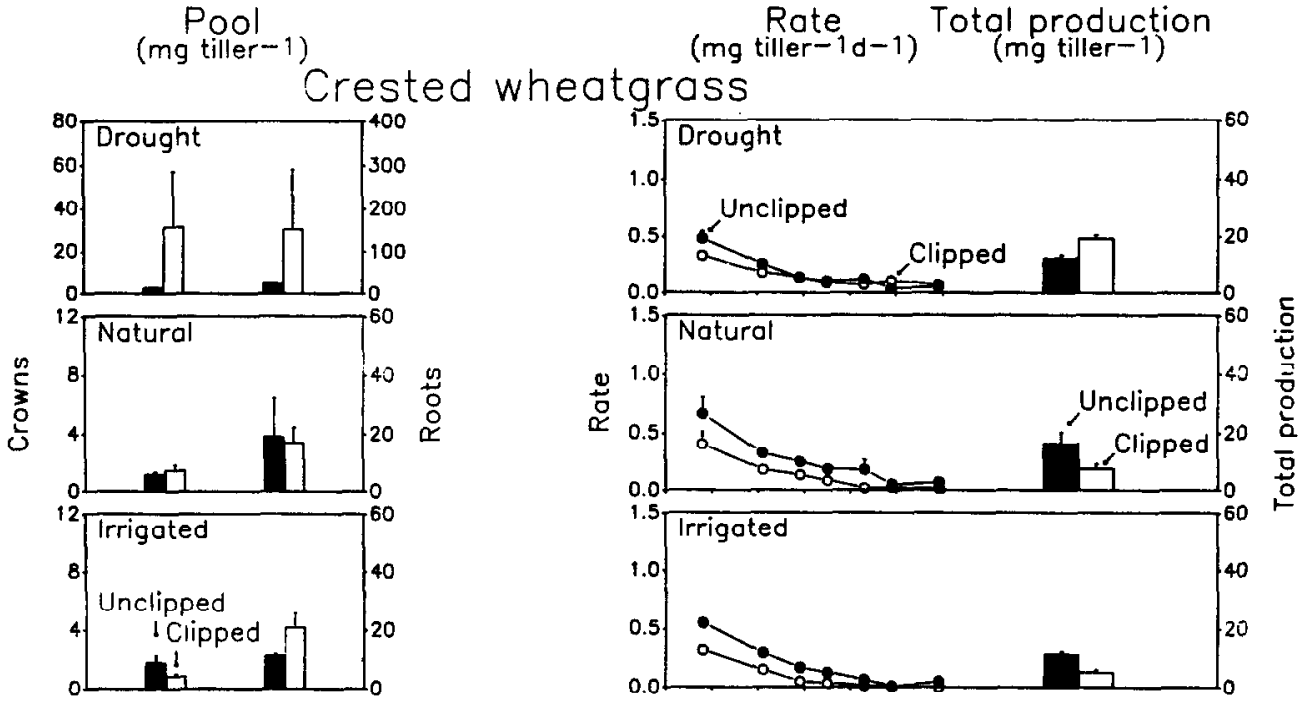

Fig. 3. Crown and root total nonstructural carbohydrate (TNC) concentrations (left panels) and pools (middle panels) at the initiation of the dark regrowth experiment in April 1986, and the time course of leaf blade dark regrowth rate and total dark regrowth (blades plus stems and sheaths) (right

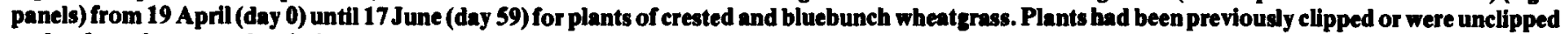

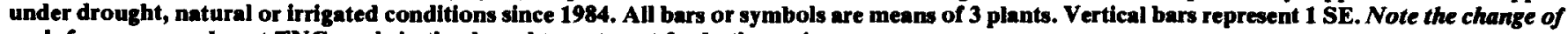
scale for crown and root TNC pools in the drought treatment for both species.

\section{Total Nonstructural Carbohydrate Analysis}

Total nonstructural carbohydrates (TNC) were determined as described by Chatterton et al. (1986). TNC determined in this manner included glucose, fructose, sucrose, and both soluble and insoluble starch and fructan. Roots near the stem bases (soil-block roots) had $\mathbf{4 0 - 3 8 0 \%}$ higher TNC concentrations than more distal roots (soil-core-roots) and thus were processed separately. Root TNC was calculated as a weighted average between roots of the soil block and roots of the soil cores.

\section{Results}

\section{Soil Water Status}

During the 1984-1986 growing seasons, soil water potentials averaged over all depths (Fig. 1) were generally 2 times lower in the drought than in the irrigated treatment. The natural plot had soil water potentials similar to or slightly lower than those observed in the irrigated plot, where values were usually $>-1.0 \mathrm{MPa}$ at all depths.

\section{Total Nonstructural Carbohydrates Concentrations}

With a few exceptions, early spring TNC concentrations of crowns and roots at the initiation of the dark regrowth experiments were not significantly different between plants clipped once the previous year(s) and unclipped plants when comparisons were made within species for 1985 (Fig. 2) and 1986 (Fig. 3). Exceptions were in bluebunch wheatgrass where crown TNC concentrations in the drought treatment and root TNC concentrations in the natural treatment were lower in clipped than in unclipped plants in both years $(P=0.08)$. For both species in 1985 and 1986 TNC concentrations in crowns and roots were usually significantly greater in the drought treatment than in the natural or irrigated treatments (Figs. 2 and 3 ).

Crown TNC concentrations were reduced, to 14-84\% (1985) and $5-23 \%$ (1986) of initial values, during the dark regrowth experi- 
ments. Final root TNC concentrations were from $24 \%$ to $70 \%$ lower than initial values for all treatments in 1986.

\section{Pools}

With a few exceptions, again, crown and root TNC pools (per tiller) were similar between clipped and unclipped tillers of crested and bluebunch wheatgrass after a single heavy defoliation in both years (Figs. 2 and 3). The exceptions were significantly lower crown TNC pools of crested wheatgrass and root TNC pools of both species in clipped than in unclipped tillers under natural conditions in 1985 (Fig. 2). In 1986, TNC pools in crowns and roots did not differ significantly between clipping treatments because of high variability and only 3 samples, but apparently they were greater in clipped than in unclipped tillers of both species in the drought treatment (Fig. 3).

Crown TNC pools were usually significantly greater under drought than under higher moisture levels for clipped and unclipped tillers of both species in both years (Figs. 2 and 3). This was mainly the result of greater crown biomass per tiller in the drought treatment. Root biomass was similar or lower in the drought than in the natural or irrigated treatments in both years. However, root TNC pools were similar or greater under drought than under higher moisture regimes because root TNC concentrations were higher in tillers of both species in the drought treatment. The greatest crown and total (crown + root) TNC pools were found in clipped and drought-treated tillers of both species in 1986 (Fig. 3).

Early spring crown and root biomass of drought-exposed tillers of crested and bluebunch wheatgrass were at least 6.3 times higher in 1986 than in 1985 (Busso 1988). Crown or root TNC concentrations of these tillers, however, were higher in 1985 (Fig. 2) than in 1986 (Fig. 3). The net effect was that early spring crown and root TNC pools in the drought treatment were, on average, at least 2.7 times greater in the third (1986, Fig. 3) than in the second (1985, Fig. 2) year of successive treatment.

\section{Production of Dark Regrowth}

Initial regrowth was much faster when it occurred early in the spring (i.e., in 1986, Fig. 3) than when it occurred later in the spring (i.e., in 1985, Fig. 2). Also, consistent with Richards and Caldwell (1985), previously unclipped tillers of crested wheatgrass produced more total dark regrowth than those of bluebunch wheatgrass under natural conditions ( $P=0.08$ in both years).

The rate of leaf blade production in the dark by.previously clipped tillers of bluebunch wheatgrass, and to a lesser extent by previously clipped tillers of crested wheatgrass, was greatest in the drought treatment in 1986 (Fig. 3). Both species also produced stem plus sheath (more than $50 \%$ of total dark regrowth) at a rate greater than that of blades under these conditions. Clipped tillers of both species in the natural and irrigated treatments produced mostly leaf blades during dark regrowth (88-100\% of total production). Therefore, clipped tillers of crested and bluebunch wheatgrass produced more total dark regrowth in the drought plot than in the natural or irrigated plots (Fig. $3 ; P=0.08$ ). In contrast, the average rate of leaf blade dark regrowth and the total amount of dark regrowth produced was not significantly different between water-level treatments for control (previously unclipped) tillers of both species (Fig. 3).

\section{Carbohydrate Availability and Dark Regrowth in Spring}

Crown and root TNC concentrations at the initiation of dark regrowth were not correlated to regrowth rate (not shown, but see Figs. 2 and 3) or total production (Fig. 4). The lack of a significant relationship between TNC concentration and dark regrowth when both species, years, and all treatments were considered (Fig. 4) was supported by individual comparisons within species, year and treatment (Figs. 2 and 3). For example, when crown TNC concen-
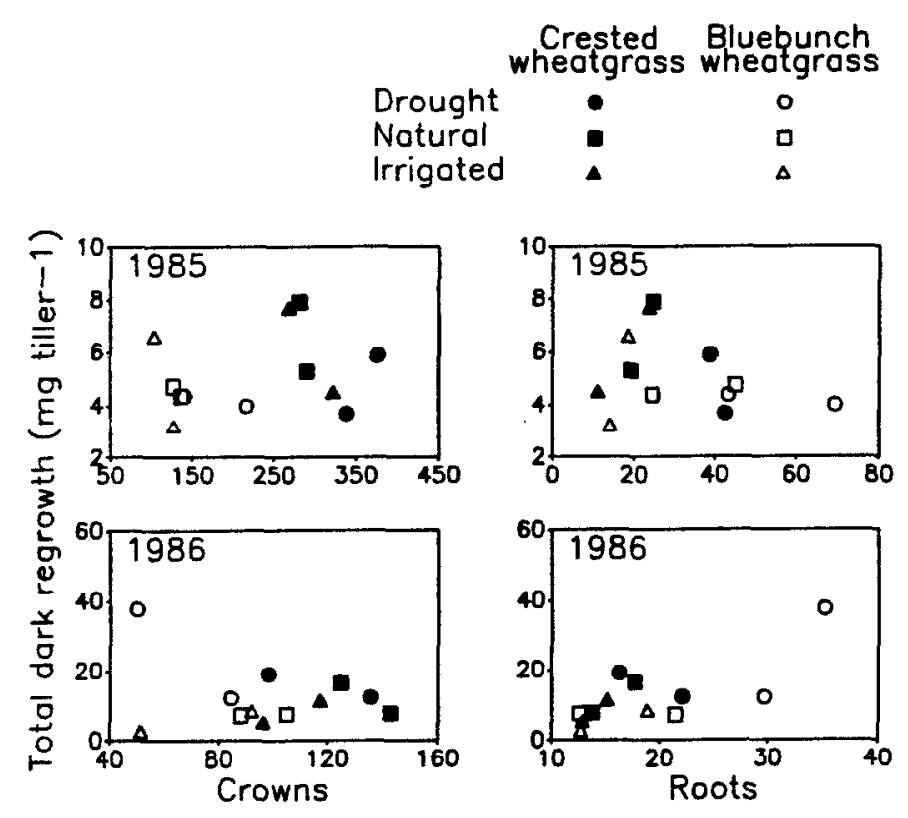

$$
\text { TNC (mg g-1) }
$$

Fig. 4. Relationship between crown or root total nonstructural carbohydrate (TNC) concentrations at the initiation of dark regrowth experiments and total production (blades plus stems and sheaths) of dark regrowth in 1985 and 1986 on plants of crested wheatgrass and bluebunch wheatgrass. Plants were previously clipped or unclipped under drought, antural or irrigated conditions since 1984. Each symbol is a mean of 3 plants.

tration was significantly greater in unclipped than clipped tillers of bluebunch wheatgrass, regrowth rate and total production were greater for clipped, not unclipped, tillers (drought treatment, 1986, Fig. 3). There was some suggestion of a positive relationship between root TNC concentration and total production of dark regrowth for bluebunch wheatgrass in 1986, but the correlation was not significant (Fig. 4) Finally, the degree of TNC depletion after regrowth ceased in 1985 and 1986 did not correlate to the amount of dark regrowth produced by clipped or unclipped tillers (Busso 1988).

In 1985, there was no relationship between the estimated pool of TNC in crowns or crowns plus roots and the rate (not shown, but see Figs. 2 and 3) or total amount of dark regrowth produced by crested and bluebunch wheatgrass at all water levels (Fig. 5). When a wider range of TNC pools was obtained in 1986, a positive, significant relationship was obtained for both species between crown or total TNC pools and total production of dark regrowth (Fig. 5). This relationship depended strongly on data from the drought treatment, where high TNC pools occurred. Without the drought treatment data the regressions were not significant $\left(P>0.1 ; \mathrm{r}^{2}=0.31\right.$ for crowns and 0.12 for crowns + roots). Individual comparisons within species and treatment supported this relationship when they included the very high TNC pools of droughttreated plants in 1986 (Fig. 3).

\section{Discussion}

Crown and root TNC concentrations and pools of crested and bluebunch wheatgrass were comparable to values previously reported for these species (i.e., Caldwell et al. 1981, Richards and Caldwell 1985, Chatterton et al. 1986). Although crown and root TNC concentrations and per tiller TNC pools were generally similar between clipped and unclipped plants of both species (Figs. 2 and 3, left and middle panels), the effects of the clipping treatment 
Klikoff 1973, Hsiao 1973, Deregibus et al. 1982). In agreement with this, crown and root TNC concentrations and pools were usually higher under drought than under natural or irrigated conditions in both species (Figs. 2 and 3, left and middle panels). These findings are similar to those of Trlica and Cook (1972) for crested wheatgrass and of Blaser et al. (1966), Pettit and Fagan (1974), and Drossopoulos et al. (1987) for other grasses. In our study, severely restricted soil moisture availability in the drought plot in 1985 (Fig. 1) led to particularly large accumulations of TNC in roots and crowns of both species in early spring of 1986 (Fig. 3, middle panels [note change of scale for drought treatment]).

The amount of dark regrowth produced under natural conditions was greater for unclipped tillers of crested wheatgrass than for those of bluebunch wheatgrass (Figs. 2 and 3, right panels). Richards and Caldwell (1985) attributed this response to greater efficiency of crested wheatgrass in producing new foliage from accumulated carbohydrates or to greater proportional allocation of mobilized compounds to regrowing shoot meristems. Regrowth immediately following defoliation in the light has also been shown to be greater for crested wheatgrass than for bluebunch wheatgrass (Caldwell et al. 1981, Richards et al. 1988).

Concentration of TNC in crowns or roots was an inadequate indicator of dark regrowth production in early spring (Fig. 4). Regrowth rate and total production were sometimes high when crown TNC concentrations were low (i.e., Fig. 3, drought, bluebunch wheatgrass) and vice versa (i.e., Fig. 3, natural, crested wheatgrass). Furthermore, at times when regrowth rate and production were similar, root TNC concentrations were different (i.e., Fig. 3, natural, bluebunch wheatgrass). These results are similar to those of Richards and Caldwell (1985) for these species, of MacLeod (1965) for Bromus inermis, and of Sheard (1968) for Phleum pratense. Other studies of wheatgrass species (Trlica and Cook 1972, Daer and Willard 1981), other pasture grasses (Adegbola 1966, Adegbola and McKell 1966, Coyne and Cook 1970, Menke and Trlica 1981), and forage legumes (Graber et al. 1927, Grandfield 1935) have concluded that TNC concentration in crowns or roots was an important determinant of spring growth. These conclusions, however, were based on correlations alone or on comparisons between percentage TNC and regrowth at different times during the growing season. In addition to TNC concentration, many other factors affecting regrowth, such as meristem availability and activity (Richards and Caldwell 1985, Olson and Richards 1988, Richards et al. 1988), vary seasonally, thus potentially confounding between-time comparisons of TNC concentration and regrowth.

Correlations between crown or total TNC pools (per tiller) and tiller dark regrowth varied between 1985 and 1986 . These variables were not correlated in 1985, but were significantly correlated in 1986 when particularly large TNC pools of the drought-treated plants were included (Fig. 5). Our results for 1985 are similar to those of Richards and Caldwell (1985), who concluded that dark regrowth of crested and bluebunch wheatgrass was more limited by the availability of active intercalary and apical meristems than by TNC availability. In early spring of 1986 , availability of active meristems did not limit dark regrowth, and dark regrowth was correlated with both crown and total (crown plus root) TNC pool size (Fig. 5). This relationship is similar to those obtained for other forage grasses (Adegbola 1966, Bommer 1966, Raese and Decker 1966) and legumes (Smith and Graber 1948).

The difference between 1985 and 1986 results supports this interpretation. Meristematic tissues were probably less active in 1985 than in 1986 because the 1985 experiment was initiated 39 days later in the season than the 1986 experiment. In addition, some apical $(\sim 10 \%)$ and leaf-blade intercalary meristems were removed at the initiation of the 1985 experiment, while only leaf 
laminae (above their intercalary meristems) were removed at the initiation of the 1986 experiment. Both of these factors may have resulted in lower shoot sink-strength in 1985 than in 1986. Shoot sink-strength can influence the production of dark regrowth (Matches 1969, Richards and Caldwell 1985).

The 1986 data suggest that accumulation of large amounts of TNC in roots and/or crowns of drought-treated bluebunch and crested wheatgrass tillers may facilitate their rapid growth in early spring, when soil moisture is normally high and apical and intercalary meristems are reactivated on overwintering tillers (Mueller and Richards 1986). Presence of many active meristems on growing tillers means that meristematic limitations to growth were minimal. In early spring 1987 , when moisture was available in all plots, leaf area was, on average $>28 \%$ greater for tillers of both species that had been exposed to drought in the previous years, and thus had high TNC contents, than for tillers on plants grown under higher moisture levels (Busso, Mueller, and Richards 1989). Rapid growth frequently occurs in perennial grasses after water stress is relieved, even when plants have been defoliated while water stressed (Hodgkinson 1976, Kigel and Dotan 1982). High growth rates of crested and bluebunch wheatgrass in early spring could allow more rapid use of water and nutrients when they are most freely available. Also, early production of a large photosynthetic surface area may establish an advantage that could remain during vegetative growth and, therefore, account for higher yields in grasses (Smith 1974, Kigel 1980). Although these benefits have been postulated, and seemed to be supported by the enhanced early spring (1987) leaf area growth of clipped, drought-treated tillers, total production by both species was reduced in the drought plot because of reduced tiller production (Busso, Mueller, and Richards 1989).

In this study, crown and root TNC concentrations of bluebunch and crested wheatgrass were poor indicators of regrowth potential in early spring. However, per tiller crown and total (crown plus root) TNC pools appeared to be positively associated with early spring tiller regrowth, at least when tillers spanning a large range in TNC pool size were compared. The stimulation of dark regrowth production per tiller in field-grown plants occurred following an experimentally imposed drought that presumably caused the large accumulation of TNC in those tillers. The results of this field study are probably representative of tiller regrowth stimulation that would occur in the early spring following severe natural droughts. Total plant regrowth would depend not only on this stimulation, but on the potentially reduced number of tillers growing after such a drought.

\section{Literature Cited}

Adegbola, A.A. 1966. Preliminary observations on the reserve carbohydrate and regrowth potential of tropical grasses. Proc. 10th Int. Grassl. Congr. 10:933-936.

Adegbola, A.A., and C.M. McKell. 1966. Regrowth potential of coastal bermudagrass as related to previous nitrogen fertilization. Agron. J. 58:145-146.

Arkin, G.F., J.T. Ritchie, M. Thompson, and R. Chaison. 1976. A rainout shelter installation for studying drought stress. Agron. J. 68:429-431.

Blaser, R.E., R.H. Brown, and H.T. Bryant. 1966. The relationship between carbohydrate accumulation and growth of grasses under different microclimates. Proc. 10th Int. Grassl. Congr. 10:147-150.

Bommer, D.F.R. 1966. Influence of cutting frequency and nitrogen level on the carbohydrate reserves of three grass species. Proc. 10th Int. Grassl. Congr. 10:156-160.

Busso, C.A. 1988. Factors affecting recovery from defoliation during drought in two aridland tussock grasses. Ph.D. Diss., Utah State Univ., Logan.

Busso, C.A., R.J. Mueller, and J.H. Richards. 1989. Effect of drought and defoliation on bud viability in two caespitose grasses. Ann. Bot. 63:477-485.
Buwai, M., and M.J. Trlica. 1977a. Multiple defoliation effects on herbage yield, vigor, and total nonstructural carbohydrates of five range species. J. Range Manage. 30:164-171.

Buwai, M., and M.J. Trlica. 1977b. Defoliation effects on root weights and total nonstructural carbohydrates of blue grama and western wheatgrass. Crop Sci. 17:15-17.

Caldwell, M.M., J.H. Richards, D.A. Johnson, R.S. Nowak, and R.S. Dzurec. 1981. Coping with herbivory: Photosynthetic capacity and resource allocation in two semiarid Agropyron bunchgrasses. Oecologia (Berlin) 50:14-24.

Chatterton, N.J., P.A. Harrison, and J.H. Bennett. 1986. Environmental effects on sucrose and fructan concentrations in leaves of Agropyron spp. p. 471-476. In: J. Cronshaw, W.J. Lucas and R.T. Giaquinta (eds.), Phloem transport. Alan R. Liss, Inc., New York.

Christiansen, S., and T. Svejcar. 1987. Grazing effects on the total nonstructural carbohydrate pools in Caucasian bluestem. Agron. J. 79:761-764.

Cook, C.W. 1966. Carbohydrate reserves in plants. Utah Resources Series 31. Utah Agr. Exp. Sta. Utah State Univ., Logan.

Cook, C.W., L.A. Stoddart, and F.E. Kinsinger. 1958. Responses of crested wheatgrass to various clipping treatments. Ecol. Monogr. 28:237-272.

Coyne, P.I., and C.W. Cook. 1970. Seasonal carbohydrate reserve cycles in eight desert range species. J. Range Manage. 23:438-444.

Daer, T., and E.E. Willard. 1981. Total nonstructural carbohydrate trends in bluebunch wheatgrass related to growth and phenology. J. Range Manage. 34:377-379.

Deregibus, V.A., M.J. Trlica, and D.A. Jameson. 1982. Organic reserves in herbage plants: their relationship to grassland management. p. 315-344. In: M. Rechcigl, Jr. (ed.), CRC handbook of agricultural productivity. Volume I. Plant productivity. CRC Press Inc., Boca Raton, Flor.

Dewey, D.R., and K.H. Asay. 1975. The crested wheatgrasses of Iran. Crop Sci. 15:844-849.

Dina, S.J., and L.G. Klikoff. 1973. Effect of plant moisture stress on carbohydrate and nitrogen content of big sagebrush. J. Range Manage. 26:207-209.

Drossopoulos, J.B., A.J. Karamanos, and C.A. Niavis. 1987. Changes in ethanol soluble carbohydrates during the development of two wheat cultivars subjected to different degrees of water stress. Ann. Bot. 59:173-180.

Graber, L.F., N.T. Nelson, W.A. Luekel, and W.B. Albert. 1927. Organic food reserves in relation to the growth of alfalfa and other perennial herbaceous plants. Wisconsin Agr. Exp. Sta. Res. Bull. 80.

Grandfield, C.0.1935. The trend of organic food reserves in alfalfa roots as affected by cutting practices. J. Agr. Res. 50:697-709.

Heilmeler, H., E.D. Schulze, and D.M. Whale. 1986. Carbon and nitrogen partitioning in the biennial monocarp Arctium tomentosum Mill. Oecologia (Berlin) 70:466-474.

Hodgkinson, K.C. 1976. The effects of frequency and extent of defoliation, summer irrigation, and fertilizer on the production and survival of the grass Danthonia caespitosa Gaud. Aust. J. Agr. Res. 27:755-767.

Hsiao, T.C. 1973. Plant responses to water stress. Ann. Rev. Plant Physiol. 24:519-570.

Humphreys, L.R., and A.R. Robinson. 1966. Subtropical grass growth. 1 . Relationship between carbohydrate accumulation and leaf area in growth. Qld. J. Agr. Anim. Sci. 23:211-259.

Kigel, J. 1980. Analysis of regrowth patterns and carbohydrate levels in Lolium multiflorum Lam. Ann. Bot. 45:91-101.

Kigel, J., and A. Dotan. 1982. Effect of different durations of water withholding on regrowth potential and non-structural carbohydrate content in rhodes grass (Chloris gayana Kunth). Aust. J. Plant Physiol. 9:113-120.

Ludlow, M.M. 1986. Simultaneous pressure of water stress and defoliation in rangeland plants. p. 433-436. In: P.J. Joss, P.W. Lynch and O.B. Williams (eds.), Rangelands: A resource under siege. Cambridge Univ. Press, Cambridge, England.

MacLeod, LB. 1965. Effect of nitrogen and potassium fertilization on the yield, regrowth, and carbohydrate content of the storage organs of alfalfa and grasses. Agron. J. 57:345-350.

Matches, A.G. 1969. Influence of cutting height in darkness on measurement of energy reserves of tall fescue. Agron. J. 61:896-898.

Menke, J.W., and M.J. Trlica. 1981. Carbohydrate reserve, phenology and growth cycles of nine Colorado range species. J. Range Manage. 34:269-277.

Menke, J.W., and M.J. Trlica. 1983. Effects of single and sequential defoliations on the carbohydrate reserves of four range species. J. Range Manage. 36:70-74. 
Mueller, R.J., and J.H.Richards. 1986. Morphological analysis of tillering in Agropyron spicatum and Agropyron desertorum. Ann. Bot. 58:911-921. Norton, B.E., and P.S. Johnson. 1983. Pattern of defoliation by cattle grazing crested wheat grass pastures. p. 462-464. In. J.A. Smith and V.W. Hayes (eds.). Proc. XIV Int. Grassland Congress. Westview Press, Boulder, Colo.

Norton, B.E., and P.S. Johnson. 1986. Impact of grazing on crested wheatgrass in relation to plant size. p. 275-279. In: K.L. Johnson (ed.), Crested wheatgrass: its values, problems and myths. Symposium Proceedings. Utah State University, Logan, Utah.

Olson, B.E., and J.H. Richards. 1988. Tussock regrowth after grazing: intercalary meristem and axillary bud activity of tillers of Agropyron desertorum. Oikos 51:374-382.

Pettit, R.D., and R.E. Fagan. 1974. Influence of nitrogen and irrigation on carbohydrate reserves of buffalograss. J. Range Manage. 27:279-282.

Raese, J.T., and A.M. Decker. 1966. Yields, stands persistence, and carbohydrate reserves of perennial grasses as influenced by spring harvest stage, stubble height, and nitrogen fertilization. Agron. J. 58:322-326.

Richards, J.H., and M.M Caldwell. 1985. Soluble carbohydrates, concurrent photosynthesis and efficiency in regrowth following defoliation: $A$ field study with Agropyron species. J. Appl. Ecol. 22:907-920.

Richards, J.H., R.J. Mueller, and J.J. Mott. 1988. Tillering in tussock grasses in relation to defoliation and apical bud removal. Ann. Bot. 62:173-179.
Sheard, R.W. 1968. Relationship of carbohydrate and nitrogen compounds in the haplocorm to the growth of timothy (Phleum pratense L.). Crop Sci. 8:658-660.

Smith, D. 1974. Growth and development of timothy tillers as influenced by level of carbohydrate reserves and leaf area. Ann. Bot. 38:595-606.

Smith, D., and L.F. Graber. 1948. The influence of top growth removal on the root and vegetative development of biennial sweetclover. J. Amer. Soc. Agron. 40:818-831.

Smucker, A.J.M., S.L. McBurney, and A.K. Srivastava. 1982. Quantitative separation of roots from compacted soil profiles by the hydropneumatic elutriation system. Agron. J. 74:500-503.

Trlica, M.J., and C.W. Cook. 1972. Carbohydrate reserves of crested wheat grass and russian wildrye as influenced by development and defoliation. J. Range Manage. 25:430-435.

West, N.E. 1983. Western Intermountain sagebrush steppe. p. 351-374. In: N.E. West (ed.), Ecosystems of the world 5. Temperate deserts and semi-deserts. Elsevier Scientific Publ. Co., Amsterdam, The Netherlands.

Zar, J.H. 1984. Biostatistical analysis. Prentice-Hall, Englewood Cliffs, N.J.

\section{From SRM. . .}

A History of the Soclety for Range Management, 1948-1985 by Clinton H. Wasser, Elbert H. Reid, and Arthur D. Smith. Based on the philosophy that any society that does not know its own history is doomed to repeat its mistakes, purchase of this publication is a must for all leaders and would-be-leaders of the Society. Besides that, it's just plain interesting to read. You may even find that your own name "has gone down in history!" 76 pages $81 / 2$ by 11 , illustrated, indexed, soft cover, $\$ 10.00$ US.

Quotable Range Quotes II compiled by E. William Anderson. This second edition provides 366 "quotable quotes" from JRM, Rangeman's News, Rangeman's Journal, and Rangelands, covering the period from 1948 to 1982. A Reference Cited chart identifies the speaker, title of the article, and published source. Ideal for those who speak and write about range management frequently. 56 pages, $81 / 2$ by 11 , spiral bound, soft cover, $\$ 7.50$.

These books and many more on range management and related topics are available from the Society for Range Management, 1839 York St., Denver, CO 80206. Telephone: (303)355-7070. 